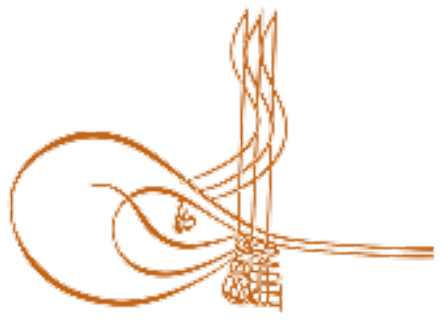

www.turkishstudies.net/language
Turkish Studies - Language and Literature

eISSN: $2667-5641$

Research Article / Araştırma Makalesi

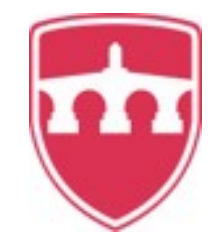

INTERNATIONAL BALKAN

UNIVERSITY Sponsored by IBU

\title{
Hırvatistan'dan Bir Çocuk Romanı: Çırak Hlapić'in Olağanüstü Maceraları” Adlı Eserin Çocuğa Görelik İlkesi Bakımından İncelenmesi
}

\author{
Examination of the Children's Novel from Croatia Named "The Extraordinary Adventures \\ of Apprentice Hlapić" in Terms of the Principle of Relativity to the Child
}

\author{
Demet Kardaş ${ }^{*}$
}

\begin{abstract}
For people, childhood includes a period that is universal. The importance of this period in some societies was understood early but in some recognized later. The idea that the child should be educated systematically, especially in in Western societies, has formed the foundations of children's education and literature. Children's Literature of the Croatians, who had traveled throughout Europe from the Balkans to Europe during the history, started from the 17th century onwards, but the most important works began to be given towards the end of the 19th century. Even though we're connected with strong historical bonds, Croatian literature is not well known in Turkey. However, the children's novel The Apprentice Hlapić's Extraordinary Adventures which was written in 1913 by Ivana Brlić Mažuranić which was translated into hundreds of languages by Ivana Brlić Mažuranić in 1913, was translated into Turkish by the contribution of the CroatianTurkish Association of Rijeka and the Department of Turcology at the Faculty of Humanities and Social Sciences of the University of Zagreb. The novel was published by Nesin Publishing House Children's Paradise Library and the novel continues to sell. The aim of the study is to evaluate the children's novel Ivan The Extraordinary Adventures of Apprentice Hlapić ğ 1 written by Ivana Brlić Mažuranić in 1913 and translated into hundreds of languages in terms of internal and external structural features. In this study, the historical development of Croatian Children's Literature, external and internal structural features of the novel "The Extraordinary Adventures of Apprentice Hlapici" and it's suitability to the basic educational principles were examined. This study is a descriptive study and it is based on document analysis method. It is considered that the novel is suitable for children aged 9-12, who are target readers, in terms of external and internal structural features and educational principles.
\end{abstract}

Structured Abstract: Croatian literature is based on rich history, cultural and social heritage and Croatian author's pieces are translated into all European languages. In the Middle Ages and early modern times, such as in European, also in Croatian literature, hasn't been paid a lot of attention to children and the child psychology.

\footnotetext{
* Öğr. Gör. Dr., Gazi Üniversitesi, Türkçe Öğrenim, Araştırma ve Uygulama Merkezi, Türkçe Eğitimi. PhD, Gazi Univesity, Turkish Learning, Research and Application Center, Turkish Education. ORCID 0000-0003-0222-6794

demetkardas@gmail.com

Cite as/ Atıf: Kardaş, D. (2020). Hırvatistan'dan bir çocuk romanı: Çırak Hlapić'in Olağanüstü Maceraları" adlı eserin çocuğa görelik ilkesi bakımından incelenmesi, Turkish Studies - Language, 15(1), 279-295. https://dx.doi.org/10.29228/TurkishStudies.39564

Received/Geliş: 01 November/Kasım 2019

Accepted/Kabul: 24 March/Mart 2020

Copyright $(\mathrm{INTAC}$ LTD, Turkey 
This situation affected all areas of life, including literature and education. Croatian literary historians generally agreed that Croatian children's literature began towards the end of the 17th century. (Fališevac, 2013). Although there are more periods in the history of Croatian children's literature, the longest period is the period from the start of the 18th century until the end of the 19th century.

The books that Ivana Brlić-Mažuranić (1874-1938) wrote for children added value to children's books. Besides that, her pieces are considered a turning point in recognition of Croatian children's literature. Her first children's book is Škola i praznici, male pripovijesti i pjesme iz dječjeg života p (School and Holidays, Little Stories and Poems from Children's Life). The second book is Priče iz davnine (Stories from the Past). In these books, the author took away from reality and used imaginary places and creatures, and at the same time tried to present some facts of life to children in legends and fairy tales.

With the novel Čudnovate zgode šegrta Hlapića (The Extraordinary Adventures of Apprentice Hlapić), which was written by Brlić-Mažuranić in 1913, has ended the period of utilitarian and moral children's literature in Croatian children's literature; the era of artistic children's novel has begun. (Zima, 2001).

This novel, which was accepted as the beginning of the Croatian children's novel, was the first children's novel in Croatian literature in 1970. The story in the novel is simple, dynamic and short, and it is one of fundamental pieces in Croatian elementary education and is taught to third grade students.

In 1997, a comic strip was created by Milan Blajeković with the title "Extraordinary Adventures of Apprentice Hlapić. In 2013, the feature film of the novel was shown at the cinema. (Zima, 2013).

In Croatia, the rate of reading books is very high. Consciousness of reading books is being established in very early age. Many children's books and novels are mandatory in primary schools. One of the books that have been taught obligatory is 'The Extraordinary Adventures of Apprentice Hlapić.

This study is a descriptive study and document analysis method is used. "Document review covers the analysis of written materials with information on the facts or facts intended to be investigated" (Yildirım ve Şimşek, 2000: 140-143).

In the study, Ivana Brlić-Mažuranić's children's novel called " The Extraordinary Adventures of Apprentice Hlapić) (2006: 43-52) was examined and evaluated under the headings of external structure features and internal structure properties. In the evaluation of the novel in terms of "basic education principles', the study of Gönen $(2017$, p. 36) was utilized.

As a result of the study, it was found that the novel was suitable for target reader age group in terms of structural and educational principles, except for the external structural features e.i. illustration. It is also important that the values felt by the author, who acted from the idea that goodness, diligence, intelligence, courage are very important virtues for people, are universal.

It is considered that the author's ability to emphasize his characters, including Apprentice Hlapić, with his psychological and behavioral characteristics, rather than his physical characteristics, will have a positive impact on the children's reader. Apprentice Hlapić is a character in which every child can be identified and can act in the goodness of the child. The success of Hlapić, the author of which is set up as the representative of goodness, and Black Man, who is the representative of evil, can lead to affecting the behavior of the reader. In the novel, the idea that the Black Man is somehow found to be punished and that the good always wins is being given to the child.

The novel is also important in terms of children's education because goodness is in favor of the whole novel. The virtues of helping the elderly, children and all those in need of protection are emphasized by the greatness of sharing their bread-dinner. Apprentice Hlapić, giving the chance to Grga, advising him to do good, revealing the good person in Grga is also a very important message for the child reader. In this century, when the number of selfish, self-conscious children is rapidly increasing, such novels are considered to be useful for children. This novel, which is examined according to the titles of children's works and evaluated in terms of educational principles, is recommended to all children starting from the fifth grade, since it has tendence to both provoke interest in children for reading and help them to gain the reading habit. 
Keywords: Children's Literature, Croatian Children's Literature, Ivana Brlić Mažuranić, The Appentice Hlapić's Extraordinary Adventures, Child Education.

Öz: İnsanlar için çocukluk, evrensel bir yaş dönemini kapsamaktadır. Bu dönemin önemi, kimi toplumlarda erken anlaşılmışken kimi toplumlarda bu süreç daha geç fark edilmiştir. Özellikle Batı toplumlarında çocuğun sistematik bir şekilde eğitilmesi gerektiği fikri, çocuk eğitiminin ve edebiyatının temellerini oluşturmuștur. Tarih boyunca Balkanlardan Avrupa'ya geçiş güzergâhında bulunan Hırvatların Çocuk Edebiyatı 17. yüzyıldan itibaren başlasa da en önemli eserler, 19. yüzyılın sonlarına doğru verilmeye başlanmıştır. Güçlü tarihsel bağlarımız olan Hırvatların edebiyatı Türkiye'de pek bilinmemektedir. Ancak Rijeka Hırvat-Türk Derneği ve Zagreb Üniversitesi Felsefe Fakültesi Türkoloji Bölümünün katkılarıyla 2014 yılında Ivana Brlić Mažuranić'in 1913 yılında yazdığı yüzlerce dile çevrilmiş olan "Çırak Hlapić'in Olağanüstü Maceraları" adlı çocuk romanı Türkçeye kazandırılmıştır. Roman, Nesin Yayınevi Çocuk Cenneti Kitaplı̆̆ tarafından basılmış, romanın satışı devam etmektedir. Çalışmanın amacı, Ivana Brlić Mažuranić’in 1913 yılında yazdığı ve yüzlerce dile çevrilmiş olan "Çırak Hlapić'in Olağanüstü Maceraları" adlı çocuk romanının iç ve dış yapısal özellikleriyle birlikte çocuk eğitimi açısından değerlendirmektir ve Hırvatların ilk çocuk romanını tanıtmaktır. Bu çalışmada, Hırvat Çocuk Edebiyatının tarihsel gelişimini, "Çırak Hlapić'in Olağanüstü Maceraları" adlı romanın "dış yapı ve içyapı özelliklerini, temel eğitim ilkelerine uygunluğunu" incelenmiştir. Bu çalışma, betimsel nitelikte bir araştırma olup çalışmada doküman incelemesi yöntemi esas alınmıştır. Romanın, dış ve iç yapısal özelliklerinin ve eğitsel ilkeler bakımından hedef okuyucu olan 9-12 yaş grubu çocuk için uygun olduğu değerlendirilmektedir.

Anahtar Sözcükler: Çocuk Edebiyatı, Hırvat Çocuk Edebiyatı, Ivana Brlić Mažuranić, Çırak Hlapić’in Olağanüstü Maceraları, Çocuk Eğitimi.

\section{Giriş}

Dünya üzerindeki yüzlerce ülkenin, toplumun ve topluluğun dili, dini, sosyo-ekonomik ve kültürel ilişkileri birbirinden farklıdır ancak bütün toplumlarda aynı olan şey; çocukların masumiyeti, eğitilebilirliğidir. $\mathrm{Bu}$ ortaklığın izlerine çocuk edebiyatında rastlanılabilir. Çocuk edebiyatı eserlerinin çocuğun dil ve anlama düzeyine göre yani "çocuğa göre" hazırlanması gerekmektedir. "Çocuğa görelik, onun ilgilerini, gereksinimlerini, dil evrenini göz önünde tutmayı, hazırlanacak okuma metnini bunlarla örtüşmeye zorlar" (Sever, 2017, s.17). Metinlerin "çocuğun, yaşama ve insana yönelik deneyimlerini zenginleştirmesi ve duyarlık kazanması için, kurmaca bir gerçeklik içinde serüvene çıkması gerekir" (Çer, 2016, s.1401). Çocuğu geleceğe hazırlayan metinlerde birtakım değerlerin olması gerekmektedir.

Sevgi, saygı, fedakârlık, cesaret, iyilik, adalet gibi temaları ele alması, çocuk edebiyatının öğreticiliğini ön plana çıkarmaktadır. Çocuk edebiyatı ürünleri, estetikten uzak öğretici çocuk edebiyatını öncelememelidir. "Edebiyat ders verme aracı değildir. Edebiyatta siz hayata gider, hayatın içine girer orada dolanırsınız. Keşfeder, sorgular, sorar, kendi sonuçlarınızı çıkarırsınız. Edebiyat ders vermez ama hayatın içinde siz o yolculuklardan çok şey öğrenirsiniz. O yolculuğu yaşamak önemlidir" (Neydim, 2013). Yazınsal ürünler, "gerçeği farklı bir biçimde dile getirirken kendine özgü anlatım biçimlerinden ve yöntemlerinden yararlanır." (Dilidüzgün, 2018, s.15). Bu nedenle sanatsal metinleri okuma okurun metni anlama ve yorumlama becerisini, estetik duyarlılığını geliştirmede en önemli adımdır.

Sever (2017, s. 17) çocuk edebiyatını "Erken çocukluk döneminden başlayıp ergenlik dönemini de kapsayan bir yaşam evresinde çocukların dil gelişimi ve anlama düzeylerine uygun olarak duygu ve düşünce dünyalarını sanatsal niteliği olan dilsel ve görsel iletilerle zenginleştiren ve beğeni düzeylerini yükselten ürünlerin genel adı" şeklinde tanımlayarak çocuk edebiyatı ürünlerinin sanat, zevk ve beğeni özelliklerini ön plana çıkarmaktadır. Hırvat edebiyat tarihçileri de bu konuda benzer fikirleri ifade etmektedirler. 
Geleneksel çocuk edebiyatının tüm eserlerinde iyi davranışın ödüllendirildiği; kötü davranışın ise cezalandırıldığı belirtilmektedirler. Çocuk edebiyatına faydacılık bakış açısıyla bakıldığını ve bu nedenle de Hırvat çocuk edebiyatının sanatsal ve estetik potansiyelinin geç fark edildiğinin altını çizmektedirler (Crnković ${ }^{1}$, 1978). Çağdaş Hırvat çocuk edebiyatçıları, çocuklara yönelik yazılan eserlerin; çocuğun toplumsal ve estetik gelişime yararlı olması gerektiği üzerinde dururlar. Bu eserlerin, çoğu zaman sadece çocuklar tarafından okunduğunu, çocukların; dünya görüşünün, ilgilendiği konuların, algı derinliğinin, hassasiyetlerinin ve deneyimlerinin büyüklere kıyasla farklı olduğunu; bu nedenle herhangi bir edebî eserin çocuklar için uygun olamayacağını vurgulamaktadırlar. Ayrıca 1980'li yıllardan itibaren tarz ve kullanılan dil konusunda çocuk edebiyatından farklı olarak genç ve yetişkin edebiyatı gelişmeye başlamıştır. Težak (2010), çocuk edebiyatını "gerçek çocuk edebiyatına ait olan eserlerden oluşan" birinci grup; "çocuk edebiyatı ile yetişkin edebiyatı arasında 'kenarda kalan' eserlerden oluşan” ikinci grup olarak ikiye ayırmaktadır.

\subsection{Hırvat Çocuk Edebiyatının Tarihsel Gelişimi}

Orta çağ ve erken modern çağda çocuk psikolojisinin özel niteliklerine ilgi gösterilmediğinden Avrupa ve Hırvat Edebiyatında çocuklara ve çocukluğa nadiren dikkat edilmiştir. $\mathrm{Bu}$ durum edebiyat ve eğitim dâhil olmak üzere hayatın tüm alanlarını etkilemiştir. Hırvat edebiyat tarihçileri, Hırvat çocuk edebiyatının 17. yüzyılın sonlarına doğru başladığı konusunda genellikle hemfikir olmuşlardır (Fališevac, 2013). Hırvat çocuk edebiyatı tarihinde çeşitli süreçler bulunmakla beraber en uzun dönem, 18. yüzyılda başlayan 19. yüzyılın sonlarına kadar devam eden dönemdir. $\mathrm{Bu}$ dönemde çocuklar için ögretim ve mesaj amaçlı ilk eserleri yazanlar elbette öğretmenler olmuşlardır.

Bu dönemde çocuk edebiyatı yavaş ilerlemiştir. Antun Kanižlić'ın 1754 yılında Allah'ın varlığını çocuklara açıklamak için yazdığı "Obilato mliko duhovno" (Bereketli Manevi Süt) adlı dinsel içerikli eser, ilk Hırvat çocuk kitabı ve halk edebiyatının bir parçası olarak değerlendirilmektedir. 19. yüzyılın ortasına gelindiğinde çocuk kitaplarının az olduğu, var olanların da uyarlama veya çeviri kitaplar olduğu bilinmektedir. Hırvat çocuk edebiyatının sürekli ve gerçek gelişimi, 19. yüzyılın ortasından sonra başlamıştır. Ivan Filipović'in "Mali tobolac raznog cvetja" (Çiçeklerle Dolu Küçük Sepet) adlı eseri Hırvat çocuk edebiyatının gerçek başlangıcı kabul edilmektedir. Çünkü şiir ve dizeli atasözlerinden oluşan bu eserde öykü ve vatansever düşünceler de bulunmaktadır. Filipović kendi eserlerinin, tercüme eserlerin ve çocuk dergilerinin yayımlanmasından ibaret olan çocuk edebiyatı alanında kesintisiz çalışmalara bu eserle başlamıştır. Hırvat eğitsel-edebi kurulu tarafından Filipović'e çocuk dergisi yayımlama görevi verilmiştir (Batinić, 2004).

Sanatsal değeri yüksek olan eserlerin yazılmasıyla hızlı bir şekilde gelişim gösteren çocuk edebiyatının Hırvatistan'da gelişimi çocuk dergiciliği için uygun bir ortam sağlamıştır. "Smilje" (Ölmeyen Çiçek) olarak adlandırılan ve en uzun yayın hayatına sahip olan "Smilje" ve ikinci sırada yer alan" "Bosiljak" (Fesleğen) dergileri, çocuklarda kitap okuma isteği uyandırma ve yazarlara metinlerini yayımlama firsatını sunmayı amaçlamıştır. Bu dergiler, çocuğa sanatsal veya edebî bir

\footnotetext{
${ }^{1}$ C c- Bu harf Türkçe sözcüklerdeki [ts] seslerinin birleşimi gibi okunur.

Ć ć- harfi Türkçe [çe] gibi okunur. Bu harf çoğunlukla sözcük sonunda yer alır.

Č č- harfi Türkçe [çe] gibi okunur.

Đ d- harfi Türkçe [ce] gibi okunur.

Dž dž- harfi Türkçe [ce] gibi okunur.

$\mathbf{J} \mathbf{j}$ - harfi Türkçe [ye] gibi okunur.

Lj lj- harfi Türkçe [ly] gibi okunur. Ancak buradaki "y” sesi çok kısa ve belirsizdir.

Nj nj- harfi Türkçe [ny] gibi okunur. Buradaki “y” sesi çok kısa ve belirsizdir.

Š š- harfi Türkçe [şe] gibi okunur.

Ž ž- harfi Türkçe [je] gibi okunur (Boşnakça-Türkçe, Türkçe-Boşnakça Standart Sözlük, 2012).
} 
zevk kazandırmaya yönelmemiş; çocuğu yetiştirmeyi ve ona bir bakış açısı kazandırmayı hedeflemiştir (Plašagić, 2003). Zaman içinde çocuk dergiciliği yerini yavaş yavaş çocuk kitaplarına bırakmaya başlamıştır.

Birinci ve İkinci Dünya savaşlarıyla kesintiye uğrayan Hırvat çocuk edebiyatında köklü değişimler 70'li yıllardan sonra gerçekleşmiştir. Çağdaş yazarlar, anlatım yerine şaka ve oyunları tercih etmişlerdir. Sunčana Škrinjarić (1931-2004), geleneksel masallara dayanan modern hikâyeciliği geliştirmiştir. 90'lı yılların sonuna doğru eski efsane veya geleneksel masallara dayanan kurmaca eserlere ilgi büyümüş̧ür. Bu eserlerin esas konusu, geleneklere zarar veren bozulma ve yozlaşmadır (Zima, 2011). Kurmaca unsurları içeren edebiyatla birlikte gerçekçi edebiyat da gelişmiştir.

Toplumsal sorunları gerçekliğiyle eğitsel ve aydınlanma bakış açısıyla "Vlak u snijegu" (Kardaki Tren), "Djeca Velikog Sela" (Büyük Köyün Çocukları) ve "Družba Pere Kvržice" (Pero Kvržica'nın Arkadaşları) adlı romanlarını yazan Mato Lovrak (1899-1974), çağdaş Hırvat çocuk romanının da kurucusu kabul edilir. Lovrak'ın romanlarının en önemli özelliği, okuyucuyu sürükleyen akıcılık, maceracılık, gerilim ve espridir. Diğer bir yazar da "Uzbuna na Zelenom Vrhu" (Yeşil Tepedeki Şamata) ve "Koko i duhovi" (Koko ve Cinleri) adlı romanlarıla Ivan Kušan (19332012)'dır. Kušan'ın romanlardaki çocuk karakterler; değişken zaman-mekân algısıyla ve aksiyon dolu serbest anlatım tarzıyla aktarılmıştır (Hameršak ve Zima, 2015).

\subsection{Hırvat Çocuk Edebiyatında Ivana Brlić-Mažuranić}

İvana Brlić-Mažuranić, Ogulin şehrinde 18 Nisan 1874 tarihinde doğmuştur. Ailesi, en ünlü Hırvat asil ailelerinden biridir. Zagreb'de kız okulunda eğitim almıştır. Eserlerini yazacak kadar Almanca, Fransızca ve Rusça bilen yazarın İtalyanca ve İngilizceyi de anladığı bilinmektedir. BrlićMažuranić'in yazdığı ilk eser, memleketine adanmış "Zvijezdi moje domovine" (Vatanımın Yıldızına) adlı bir şiirdir. Evlendikten sonra Bosna-Hersek sınırının yanında bulunan Hırvatistan şehri Slavonski Brod'a taşınmış, çalışmalarına orada devam etmiştir (Crnković, 1970).

Yazar, 1913 yılında Zagreb'de "Çırak Hlapić'in Olağanüstü Maceraları" adlı eserini yayımlamıştır. Üç yıl sonra en ünlü eseri "Priče iz davnine" (Geçmişten Öyküler) yayımlanmıştır. Bu eser, yazarın öykülerindeki sanatsal değeri ortaya çıkarmıştır. Dünya edebiyat çevrelerince büyük ilgi gören eser; İngilizce, Lehçe, İsveççe, Danca gibi Avrupa dillerine ve hatta Çinceye çevrilmiştir. 1931 ve 1937 y1lında Nobel Edebiyat Ödülü’ne aday gösterilmiş, Brlić-Mažuranić, Hırvat kültürüne katkılarından dolayı 1937 yılında Hırvat Bilim ve Sanat Akademisine üye olarak seçilen ilk kadın yazar unvanını almıştır. 1939 yılında hayata gözlerini kapayan yazar, Zagreb'de "Mirogoy" mezarlığında yatmaktadır. Hırvatistan'da "Hırvat Andersen" lakabiyla bilinen Brlić-Mažuranić'in Hırvat edebiyatındaki önemi, Hırvat çocuk edebiyatına bir kimlik kazandırmasıdır. (MihanovićSalopek, 1997).

\subsection{Hırvat Çocuk Edebiyatında "Çırak Hlapić'in Olağanüstü Maceraları" Adlı Roman}

İvana Brlić-Mažuranić'in hayal gücünü, anlatımda sadeliği ve samimi mizah anlayışını özgün bir şekilde ortaya koyduğu "Çırak Hlapić'in Olağanüstü Maceraları" adlı romanı, konusunu gündelik hayattan almıştır. Romanın adındaki maceralar; olağanüstü olarak tanımlansa da muhtemel gerçekliğe ve doğruluğa sahiptir. Konusu, romanın adı olan bu eser, bir kunduracı çırağının yedi günlük yolculuğunu anlatmaktadır (Diklić, 1997).

Hırvat çocuk romanının başlangıcı kabul edilen bu roman, 1970 yılında Hırvat edebiyatındaki ilk çocuk romanı ilan edilmiştir. Romandaki hikâye, basit, dinamik ve kısadır. Bu nedenle Hırvatistan ilköğretim temel eserleri arasında bulunmakta ve üçüncü sınıf öğrencilerine zorunlu okutulmaktadır. 1997 yılında Milan Blajeković tarafından roman, "Çırak Hlapić'in Olağanüstü Maceraları" adıyla çizgi film yapılmış; 2013 yılında ise romanın uzun metrajlı filmi sinemalarda gösterilmiştir (Zima, 2013). 


\section{Yöntem}

Bu çalışma, betimsel nitelikte bir araştırmada olup çalışmada doküman incelemesi yöntemi esas alınmıştır. "Doküman incelemesi, araştırılması hedeflenen olgu ya da olgular hakkında bilgi içeren yazılı materyallerin analizini kapsamaktadır" (Yıldırım ve Şimşek, 2000, s. 140-143). Çalışmada Ivana Brlić-Mažuranić'in "Çırak Hlapić'in Olağanüstü Maceraları" adlı çocuk romanı Sever' in (2006, s. 43-52) çalışmasından hareketle "dış yapı özellikleri”, "içyapı özellikleri” başlıkları altında incelenmiş ve değerlendirilmiştir. Romanın, "temel eğitim ilkeleri" açısından değerlendirilmesinde Gönen' in (2017, s. 36) çalışmasından yararlanılmıştır.

D1ş yap1 (biçimsel) özellikleri: boyut, kâğıt, kapak-cilt, sayfa düzeni, harf büyüklüğü ve resimleri) kapsamaktadır. İçyapı (içerik) özellikleri ise konu (çatışmalar, rastlantısallık, abartılmış merak, aşırı duygusallık), izlek (tema), plan, iletiler, karakterler, dil ve anlatım) alt başlıklarından oluşmaktadır. Dil ve anlatım bölümünde bir çeviri olan romanın çevirisi de değerlendirilmiştir. Temel eğitim ilkeleri ise çocuk edebiyatında olması gereken özellikleri içeren sorulara cevaplar şeklinde açıklanmıştır. Bulguların güvenirliğine ilişkin olarak Hırvat ve Türk, iki akademisyenin kontrolü sağlanmıştır. Kitabın ikinci baskısı henüz yapılmamıştır.

Kitabın Adı: Çırak Hlapić'in Olağanüstü Maceraları

Kitabın Yazarı: Ivana Brlić-Mažuranić

Kitabı Çeviren: Zinnur Ameti

Resimleyen: Nesrin Sağlam

Yayınevi: Nesin Yayınevi (Çocuk Cenneti Kitaplığı)

Basım Yılı: 2014 (1.Baskı)

Sayfa Sayısı: 128

\section{Görsel 1. Kitabın Kapağı}

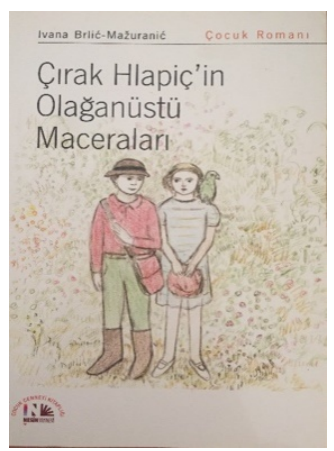

Görsel 2. Kitabın Arka Kapağı

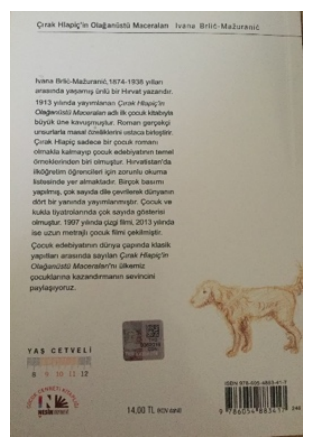

\section{BULGULAR}

\subsection{Kitabın Dış Yapı Özelliklerine İlişkin Bulgular}

\subsubsection{Boyut}

Kitap 13,5x21 boyutundadır. Kitabın ağırlığı ise yaklaşık 250 gr kadardır. Kitap, çocuğun taşıyabileceği ağırlık ve boyuttadır. Bu açıdan 9-12 hedef yaş grubu çocuk için ideal bir kitaptır. 


\subsubsection{Kapak-Cilt}

Ön kapakta kitabın adı ve yazarın adı, kitabın türü ve yayınevinin logosu bulunmaktadır. Çocuklar kitapları taşırken veya okurken kitabı koruma anlamında dikkatli olmayabilirler bu nedenle kitabın cildi ve kapağı sağlamlığı nedeniyle çocuklar için uygundur.

Kitabın adı, "olağanüstü maceralar" tanımlamasıyla ilgi çekicidir. Kitabın adıyla Çırak Hlapić'in yaşadığı olaylar birbiriyle örtüşmektedir. Kapak resmi Çırak Hlapić’i ve Hlapić'in yolda karşılaştığı Gita ile Gita'nın papağanını resmetmektedir. Çırak Hlapić'e yolculuğu boyunca eşlik eden köpeği Kürklü ise kitabın arka kapağında resmedilmiştir. Kapak resimleri, Çırak Hlapić ve kitabın konusuyla ilgilidir. Ancak kapak, kitapta yer alan diğer resimler gibi basit, renkli kara kalem çalışmasıdır. Kapak, çok sadedir ve kapakta kullanılan renkler çarpıcı veya göz alıcı değildir. Pastel tonlardaki bu kapak, renklerden hoşlanan çocuklara ilgi çekici gelmeyebilir. Arka kapakta yazar hakkında bir cümle ve çalışmada daha önce bahsedildiği gibi bu çocuk romanının öneminden ve Türkiye'ye kazandırılmasından dolayı mutluluk ifade eden uzun bir paragraf yer almaktadır.

\subsubsection{Kâğıt}

Kâğıt, enzo kâğıdı olarak bilinen mat görünümlü 2. hamur kâğıttır. Kâğıt, normal kâğıttan veya saman kâğıdından kalın olduğu için dayanıklıdır ve kolayca yıpranmaya karşı dayanıklıdır. Böylece üzerine bir şey yazılabilmesi veya çizilebilmesi için idealdir. Kâğıdın kalitesi açısından kitap, çocuklar için uygundur.

\subsubsection{Sayfa Düzeni}

Kitapta, A5 sayfa düzeni tercih edilmiş; kitabın sayfa kenar boşlukları, okuma kolaylığı sağlayacak şekilde düzenlenmiştir. Satır araları $1,5 \mathrm{~cm}$ 'dir bu da gözü yormaması ve satır takibi açısından idealdir. Sayfalardaki sağ ve sol kenar boşlukları 1,5 cm, üst boşluk 2,3 cm, alt boşluk 1,7 cm'dir. Resimler sayfa düzeni içerisinde bölümlere, bölüm başında, ortasında veya sonunda eşit sayıda ve Çırak Hlapić'in maceralarındaki dönüm noktalarına göre resmedilmemiştir. Önemli olayların resmedilmesi çocukta merak duygusunu canlı tutması ve metinle görsel bağ kurması açılarından romanın eksik olduğu değerlendirilmektedir. Kitabın sayfa düzeni, çocukların rahat okuyabileceği özelliktedir.

\subsubsection{Harf Büyüklüğü}

Kitapta başlıklar ve metinler farklı puntodadır. Başlıklar 18; metinler ise 14 punto ile yazılmıştır. Punto büyüklügü kitabın hedef okuyucu yaş grubunun göz ve kas gelişim düzeyine uygundur. Kitap Hırvatçadan çevrildiği için Hırvatçadaki harfler Türkçe harf sistemine uyarlanmıştır (ć harfi ç; j harfi y; ž harfi j).

\subsubsection{Resim}

128 sayfalık kitabın, 31 sayfasında Nesrin Sağlam'ın renkli-renksiz kara kalem tarzıyla çizdiği resimler kullanılmıştır. Resimlerde, kitabın kapağında da olduğu gibi pastel tonlar tercih edilmiştir. Resimler, sayfadaki olay örgüsü ile uyumludur ve sayfadaki konuyu özetleyici özellikler taşır. Çocuğun anlatılan olayı zihin dünyasında canlandırmasına imkân sağlar. Sayfada ilk göze çarpan görseller olduğu için resimler, çocuğun olaylar hakkında tahmin yürütmesi için uygundur. Ancak, resimlerin çok da profesyonel olmayan bir teknikle çizilmesinin, resimlerin kalitesiz oluşunun, belli bir çizgi standardının ve boyutunun olmayışının böylesine önemli bir kitap için uygun olmadığı değerlendirilmektedir. 


\subsection{Kitabın İçyapı Özelliklerine İlişkin Bulgular}

\subsubsection{Tema (İzlek)}

Tema, metnin konusunun anlamca ortaya koyduğu ana hedeftir. Bu hedefin, çocuklar için hazırlanan metinlerde, bazı özelliklere göre şekillenmesi gerekir: "Çocuk edebiyatı yapıtlarında yazınsal bir konu ve izlek arasında güçlü bir ilişkinin olması, metnin çocuk üzerindeki yazınsal etkisini artırır. Kurguyla geliştirilen izlek, insana özgü duygu durumlarını çocuklarda yaşatabilmeli; çocuklar kaynağını sevgiden alan konularda duyarak, gülerek, düşünerek, hüzünlenerek dostluğun, barışın, çalışkanlığın, paylaşmanın yüceliğini sezebilmeli, güven duygularını geliştirebilmelidir" (Sever, 2006, s. 48-49). Romanın ana teması; şartlar ne olursa olsun iyilik ve cesaretin insanı başarı ve mutluluğa götürmesidir. Alt temalar ise sevgiyi, çalışkanlığı, paylaşmanın ulviliğini ve asla kin tutmamak gerektiğidir. Roman, ana ve alt temalar açısından hedef okuyucu için uygundur.

\subsubsection{Konu}

Konu, "Yalın bir tanımla yazıda ya da yapıtta ve yaratıda ele alınan, üzerinde durup söz söylenen, işlenip getirilen şey" Özdemir (1995, s. 53) olarak tanımlanmaktadır. Bir yazının, kitabın konusu akla gelebilecek her şey olabilir; ancak çocuklar için yazılan bir kitabın konusu her şey olamaz. Oğuzkan'a göre, "çocuk yapıtlarında ele alınacak konu çok önemlidir. Konu seçiminde, çocukların gelişimsel özellikleri iyi bilinmelidir. Onlara katkı sağlayabilecek kültür değerlerinin ve toplumsal yapı özelliklerinin göz önünde tutulması gerekmektedir." (2006, s. 375-376). Çocukların; toplumun, geleceğin yapı taşları olduğu düşünüldüğünde çocuğa kazandırılmak istenen değerleri hissettirecek konular seçilmelidir. Konu seçiminde veya konunun genişletilmesinde hedef okuyucu yaş grubu göz önünde bulundurulmalı; konunun çocuğun ilgisini çekecek, canlı tutacak ve sürükleyecek nitelikte olmasına dikkat edilmelidir.

Çırak Hlapić'in Olağanüstü Maceraları adlı romanın konusu şöyledir: Romanda yaşı belirtilmeyen yetim bir çocuk olan Hlapić, hayatını Çatık Usta adında bir ayakkabı ustasının yanında çırak olarak geçirmektedir. Usta, geçmişte yaşadığı bir olay nedeniyle gaddar ve zalim bir adamdır ama Çatık Usta'nın karısı, çok iyi kalplidir ve Hlapić'e çok iyi davranmaktadır. Zaten Hlapić, sevgi dolu hanımı nedeniyle zalim ustaya katlanmaktadır.

Çatık Usta, zengin bir adamın oğlu için bir çift çizme yapar ancak zengin adam, çizmenin oğlunun ayağına dar olduğunu ve bu nedenle almak istemediğini söyler. Çatık Usta ne söylese de zengin adamı ikna edemez. Usta bunun acısını hiçbir suçu olmayan Hlapić'ten çıkarır ve onu çizmeyle çok kötü bir şekilde döver. Bu olaydan sonra Hlapić, ustasının yanından kaçmaya karar verir. Çizmeleri de yanına alarak güneşin doğuşuyla şehri terk eder. Yolcuğuna köpeği Kürklü de katılır. Nereye gideceğini bilemeyen Hlapić'in tek amacı, Çatık Usta'dan uzak olmaktır. Hlapić, yolculuğunun ilk saatlerinde yaşlı bir sütçüye yardım eder, daha sonra da iki kazını kaybeden Marko'nun kazlarını bulur. Gece Marko'nun evinde kalır. Sabah oradan ayrılır. Fırtınalı bir yağmura yakalanan Hlapić bir köprü altına sığınır ancak orada da çizmeleri çalınır. Çizmelerini Kara Adam çalar. Hlapić, yolculuğu boyunca yanında olacak Gita'yla karşılaşır. Bir çiftlikte iş bulurlar; ancak Gita çalışmak istemez. Hlapić ikisinin de yerine çalışır ve akşam yemeklerini kazanır. Çiftliğin yakınındaki köyde, herkesin nefret ettiği Grga'nın evinde yangın çıkar. Hlapić, büyük bir kahramanlık ve cesaret göstererek yangını söndürmek için evin içine girer hem yangını söndürür hem Grga'nın annesini kurtarır hem de kayıp tüm eşyaları ve çizmelerini bulur.

Bundan sonraki günlerde Hlapić'in yolculuğu, Grga ve Grga'nın arkadaşı Kara Adam'la mücadele etmekle geçer. Bu mücadelenin sonunda Çatık Usta'yı ve karısını, Gita'yı ve Hlapić'i büyük sürprizler beklemektedir. Romanın konusu, konunun genişletilmesi oldukça başarılıdır. Roman; bir çocuğun cesaretle, doğrulukla neler başarabileceği etrafında başarılı kurgusuyla; çocukta ilgi ve merak uyandıracak sürükleyiciliği ile hedef okuyucu için uygundur. 


\subsubsection{1. Çatışmalar}

Çocuklar dikkat süresi bakımından bir metne uzun süre ilgi gösteremezler. Dikkat süresinin uzun olmasını sağlayan ve çocuğu, metne bağlayan temel unsur çatışmadır. Ancak çocuklara göre yazılan metinler bütünü yani kitaplarda "çocuğun okuma eyleminden zevk alabilmesi için çatışmay1 yaşayan kahramanla özdeşim kurması ve öykülenen olaydaki gerilimi duyumsayabilmesi gerekir" (Sever, 2017, s. 128). Çocuk kitaplarındaki kahramanlar, kendisiyle, başka karakterlerle ve toplumla çatışabilirler. Çatışmalarda denge, anlamlılık, sevgi, saygı ve çatışmayı barışla sonuçlandırma temel alınmalıdır. "Çocukların anlamlandıramayacağı kişi-toplum çatışmalarına yer verilmesi, çocuklara üstlenemeyecekleri sorumluluklar yüklenmesi, kitabın yazınsal niteliğini zedeler" (Sever, 2017, s. 134). Çırak Hlapić'in Olağanüstü Maceraları adlı romanında, çatışmalar hedef okuyucu yaş grubu çocukların seviyesine, Türkiye'de de yaşanabilecek kadar doğal çevreye uygun, dinî veya siyasi bir düşünceyi aşılamayan, okuyucuyu bir tarafa yönlendirmeyen tarzdadır. Çatışmalar kurgusal yapıya uygun sıralanmıştır. Çalışmada, romandaki çatışmalar örnek metinlerle detaylı bir şekilde verilmektedir.

\section{a. Kişi-Kişi Çatışması}

Romandaki kişiler arasındaki ilk çatışma, Çatık Usta ile zengin beyefendi arasındaki küçük çizmelerle ilgilidir. "... Zengin beyefendi oğluyla çizmeleri almaya geldiğinde çizmeler oğluna küçük gelmiş. Bu yüzden zengin beyefendi çizmeleri almak ve parasını ödemek istememiş. Çatık Usta onunla tartışmaya başlamış ama zengin beyefendiyi ikna edememiş. " Bu olayın ardından Çatık Usta, hiçbir kusuru olmadığı hâlde Çırak Hlapić'i suçlamış. “... O çizmeler yakılacak ama sen bunun bedelini ödeyeceksin, tembel çocuk seni!” Romanda Çırak Hlapić'in yolculuğu boyunca kötü kalpli ve yalancı insanlarla ve Hlapić'e göre zayıf, güçsüz, tembel olan Gita ile iş yüzünden çatışması da yerinde kurgulanmıştır.

\section{b. Kişi-Toplum Çatışması}

Romanda Hlapić'in yolculuğu boyunca karşılaştı̆g insanlar, köy halkı, çoban çocukların ailesi, çoban çocukların köyündeki insanlar, sirkteki topluluk iyi, temiz ve dürüst insanlar olduğu için kendi aralarında veya Hlapić ile bir çatışma olmamıştır.

\section{c. Kişi-Doğa Çatışması}

Romanda, Çırak Hlapić'in yağmura, gece ayazına ve karanlığına karşı mücadelesi romanı yönlendirmiştir. "... Fakat akşamüstü birdenbire güçlü bir rüzgâr çıkmış. Şimşekler çakıp gök gürlemeye başlamış. Ardından şiddetli bir yağmur yağmaya başlamış." Yağmurdan korunmak için küçük köprü altına sığınan Hlapić, romanın kötü karakteri Kara Adam ile köprü altında tanışmış.

\section{ç. Kişinin Kendisiyle Çatışması}

Çırak Hlapić'in yolculuğu boyunca ona arkadaşlık eden Gita ile ilgili duygu ve düşünceleri onu çatışmaya itmiştir. “... Gita ağlamaya başlayınca artık yola devam etmek mümkün olmamış. Yolun kenarına oturup elleriyle yüzünü kapatmıs. Hlapić ise onun önünde duruyor ve susuyormuş. 'Ne yapacă̆ım şimdi?' diye düşünmüş Hlapić. Gita'yı gece yarısı yolda bırakamazmış ama onunla birlikte Marko'nun evine hiçbir zaman varamayacakmış." Hlapić güçlü bir karakter olduğu için kararlarını tereddüt etmeden verebilmiştir. Bu nedenle kendisiyle çatışması oldukça azdır.

Metinlerde, konuyu yapılandıran parçaların ortaya konması için kurgunun sağlam olması gerekir. Kurgunun sağlam olması, okuyucuyu metne bağlar; okuyucunun kafasını karıştırmaz.

\subsection{3. İleti (Mesaj)}

İleti, Türkçe Sözlükte "Bir kaynaktan alıcıya ulaştırılmak istenen duygu, düşünce ve becerileri içeren şeyler, yazı veya sözle verilen, gönderilen bilgi, mesaj” (TDK, 2005, s. 954) olarak tanımlanmaktadır. Her metin, bir amaç doğrultusunda kaleme alınır. Yazarın amaç doğrultusunda 
okuyucuya ulaştırmak isteği ileti, çocuklar için oluşturulan metinlerde önemli bir unsurdur. Çocuk edebiyatında metinlerde ana iletiye ek olarak ana iletinin etrafinda şekillenen yardımc1 iletiler oldukça fazladır.

\subsubsection{Ana İleti}

Romanın giriş kısmında "Gerçekten de Hlapić doğru olanı yaptı, şafak sökerken yola koyulduğunda iyi ki içinde iyilik, zekâ ve cesaret vardl." yazmaktadır. Çırak Hlapić'in yolculuğu boyunca yaşadığı olaylardan hareketle romanın ana iletisi şudur: İyi kalpli, cesur ve çalışkan insanların ödüllendirileceği; kötü kalpli, korkak ve tembel insanların ise mutlaka cezalandırılacağıdır. Bu açıdan değerlendirildiğinde roman, hedef okuyucu için uygundur.

\subsubsection{Yardımcı İletiler}

Romanın yardımcı iletilerinde ise "Fakat yine de hiçbir çocuk evinden kaçmasın. Çatık Usta'nın yanındayken Hlapić'in yaşadiğı kötülükler kimsenin başına gelmemiştir ama herkes aynı zamanda Hlapić kadar şanslı olabilir mi?" cümlesinde olduğu gibi çocukların yaşadıkları zorluklardan kaçmasının çare olmadığı mesajı vardır çünkü Hlapić, yolculuğu boyunca zorluklar yaşamıştır.

Romanın bir diğer yardımcı iletisi, kötülüğün ve gerçekten kötü olan insanların hiçbir zaman kazanamayacă̆ıdır. Romandaki kötü karakter olan Kara Adam'ın cezasını bulutların yani yaratıcı gücün vermesi de önemli bir iletidir.

Değişmek isteyen kötü insanların değişebileceği de başka bir iletidir. Grga, iyi kalpli annesinin, Çırak Hlapić'in de desteğiyle yaptığı kötülüklerden pişman olmuş ve Çatık Usta'ya yardım etmiştir.

Arkadaş seçiminin önemi de bir iletidir. Grga, Kara Adam ile arkadaş olduktan sonra hırsızlı̆̆a başlamıştır. Romanın yardımcı iletileri de eğitsel nitelikler açısından hedef okuyucu için uygundur.

\subsubsection{Karakterler}

Sever, karakteri "Sanatçının yarattığı; duygu, düşünce ve tutku yönleriyle geliştirdiğgi, gerçek yaşamdan da esinlenerek deneyimiyle, birikimiyle, kendine özgü duyarlığ ${ }_{1}$ ile biçimlendirdiği bir kişilik.” olarak tanımlamaktadır (2017, s. 75). Karakter; öykü, hikâye, roman yazarının bazen gerçek hayattan bazen de yazarın kurgusal dünyasından ortaya çıkardığ 1 kişilerdir. Çocuk kitaplarında bu karakterler içinden bir veya birkaç kahraman çıkar; bu kahramanlar yazarın ana ve yardımcı iletileri etrafında metni yaşar ve yaşatırlar. "Çocuk, hangi yaş grubunda olursa olsun, okuduğu kitapların kahramanlarıyla özdeşleşir. Çocuk kitaplarında gereğinden fazla kahraman bulunmamalı, diğer kahramanlar bir ana kahramana çevresinde açık tanımlarla ilgilendirilerek anlatılmalıdır. Çünkü çocuk karmaşık yapıları anlayabilecek, karmaşık ilişkileri yorumlayacak düzeyde değildir" (Yalçın ve Aytaş, 2017, s. 90). Romanda bir ana karakter ve yardımcı karakterler vardır:

- Çırak Hlapić: Romanın ana karakteri olarak zeki, çalışkan, güçlü, dayanıklı, iyi niyetli, yardım sever ve cesurdur. Fiziksel anlamda yaşıtlarına göre daha güçlü olan Hlapić, zorluklar karşısında pes yemeyen, karşılık beklemeden insanlara yardım eden, kendisi aç olduğu hâlde yemeğini paylaşan, sevdiklerini koruyan çok iyi yürekli bir çocuktur. Bu özelikleri sekiz günlük yolcuğunda onu ve yanındaki insanları türlü belalardan kurtarmıştır.

- Gita: Romanın yardımcı karakterlerinden olan Gita; zayıf, güçsüz ve tembel bir kız çocuğudur. Bir sirkte büyüdüğü için eğlenmeyi, eğlendirmeyi çok sevmektedir. En büyük isteği bir aileye sahip olmaktır. Zaman zaman Çırak Hlapić'e zorluklar çıkarsa da Halpiç'in yolculuğunun mutlu sonla bitmesinde önemli bir rolü vardır.

- Çatık Usta: Romanın yardımcı karakteridir. Gaddar ve zalim bir ustadır. Çırak Hlapić’e çok kötü davrandığı için Hlapić'i yolculuğuna sürükleyen de odur. Aslında romanın sonunda Çatık Usta'nın geçmişte yaşadığı büyük üzüntü, yaptıklarından pişman olması ve Çırak Hlapić'ten özür 
dilemesi, Çatık Usta'ya karşı okuyucuyu yumuşatmaktadır. Bu yardımcı mesajlar açısından önemli bir karakterdir.

- Kara Adam: Romanın kötü karakteridir. Hayatını hırsızlık yaparak geçirmektedir. Zavallı bir çocuğun çizmelerini, küçük bir kızın küpelerini, tarlada çalışan işçilerin parasını çalacak kadar vicdansız bir adamdır. Kötülüğünü Grga'ya bulaştırmış onu da hırsızlık yapmaya zorlamıştır. Yazar, kötü insanların mutlaka cezasını bulacağını Kara Adam karakteri üzerinden okuyucuya hissettirmektedir.

- Grga: Yanlış arkadaş edindiği için hırsızlığa başlayan ama sonra yaptıklarından pişman olan Grga, yazarın kötü insanların eğer isterlerse değişebileceklerini okuyucuya ilettiği bir karakterdir.

- Çatık Usta'nın Karısı: Zalim Çatık Usta'nın iyi kalpli karısıdır. Kocasının aksine Çırak Hlapić'e çok iyi davranmakta, ona fazladan yiyecek vermektedir. Yazar, bu karakteri hem Hlapić'in hem de Gita'nın eksikliğini hissettiği "anne" olarak okuyucuya göstermektedir. Zaten romanın sonundaki rastlantı da okuyucuyu buna hazırlamaktadır.

- Kürklü: Çırak Hlapić'in sadık köpeğidir. Kürklü, yolculukları boyunca Hlapić'i ve Gita'yı kötü insanlara karşı uyarmakta ve onları korumaktadır.

- Marko: Mavi yıldızlı evde annesiyle birlikte yaşayan bir kaz çobanıdır.

- Yaşlı Sütçü: Hlapić'in yolculuğunun ilk saatlerinde karşılaştığı ve yardım ettiği yaşlı sütçü, romanın sonunda kendisine yardım eden Hlapić'e ve okuyucuya büyük bir sürpriz yapmaktadir.

Romanda diğer yardımcı karakter ise Çırak Hlapić'in yolculuğu boyunca karşılaştığ Marko'nun annesi, Graga'nın annesi, köylüler, çoban çocuklar, çoban çocukların iyi kalpli anne ve babası, dilenci kadın, sirkin sahibi ve iyi kalpli sepetçidir. Tüm karakterler, çocukların günlük hayatta karşılaşabileceği insanlar gibi sıradan, doğal ve abartısızdır. Karakterlerin olağanüstü özellikleri yoktur. Karakterlerin her biri, yazarın ana ve yardımcı iletilerine, temaya ve konuya göre kurgulanmıştır. Yazar, karakterleri fiziksel özellikleriyle değil, psikolojik ve davranışsal özellikleriyle ön plana çıkarmıştır. Çocuk kitaplarında ana karakter, çocuk da olabilir yetişkin de ve bu romanda ana karakterin çocuk olması okur çocukların kahramanla özdeşim kurmasını kolaylaştırabileceği açısından hedef okuyucu için uygundur.

\subsubsection{Plan}

Romanda olaylar, kronolojik anlatımla verilmiştir. Yazar, romanı Çatık Usta'nın kendi hatasını Hlapić'e yüklemesiyle ve Hlapić'in Çatık Usta'ya tepki olarak ondan kaçmasıyla başlatmıştır. Roman, Hlapić'in ilk günden itibaren yaşadığı olaylar, gittiği köyler, tanıştığ insanlarla devam etmiştir. Yedinci günün sonunda Hlapić'in maceraları yine Çatık Usta'nın yanında mutlulukla bitmiştir. Romandaki her olayın içindeki karakter mutlaka sonraki olaylarda yer almaktadır. Romanın başında kurguya dâhil olan Gita'nın romanın sonunda Çatık Usta ve iyi kalpli karısının sirkte kaybettikleri kızları olması hem ilgi çekici hem de tutarlıdır.

Hlapić'in yedi gün süren yolculuğu esnasında yaşadıklarının temaya uygun mantıklı şekilde kurgulandığ temanın veya konunun dışında gereksiz unsurların olmamasıdır. Ayrıca Sever (2017) planda; rastlantısallık, abartılmış merak ve duygusallık gibi sorunların bozabileceğine dikkat çekmektedir.

\subsubsection{Rastlantısallık}

Metin kurgusunda, "yapıtta ele alınan konunun önemini zayıflatan, okurun kitaptaki olaylara güvenini sarsan olumsuz öğe rastlantısallıktır. Yazarın, bir rastlantıya veya şansa dayanarak öyküdeki düğümü çözmesi, çatışmayı sonuçlandırması öyküdeki olayın inandırıcılığını azaltır" Sever (2017, s. 128). Çocuk okuyucular, iyi kurgulanmayan yani okuduğunun, tahmin ettiğinin ya da beklediğinin dışında gelişen bir sonuçtan memnun olmazlar çünkü sebep-sonuç ilişkisi ekseninde 
düşünmeye ve her şeyin bir açıklaması olduğuna inanırlar. Romanda, giriş kısmında “... Zaten onun mutlu bir sona ulaşmasına çok şaşıracaksınız.” yazması, Çatık Usta'nın geçmişinde acı kayıp yaşaması, Marko'nun evinin mavi yıldızlı ev olarak anlatılması, hırsızlık vakalarının aynı sonuçla bir araya getirilmesi, Gita'nın çocukken bir panayırda kaybolması gibi detaylar, romanın sonucu hakkında çocuğa bir fikir verebilecek şekilde verilmiştir. Romanda bazı rastlantıların güzel sonuçları da okuyucuya sürpriz yapmıştır.

\subsubsection{Abartılmış Merak}

Bir metnin okunmasını sağlayan temel duygu merak duygusudur. "Çocuk okur, bazı öykülerde merak ögesinin zayıflığı ya da abartılmış olması, bazılarının da korkunçluğu nedeniyle okuma eyleminden uzaklaşır" (Sever, 2017, s. 137). Romanda, merak duygusu aşırı değildir ve özellikle romanın sonuna doğru Hlapić'in Marko'ya yardıma yetişip yetişemeyeceği, Kara Adam'a ne olduğu, Gita'nın parmağındaki bıçak izi okuyucuda merak duygusunu artırabilecek, romanın sürükleyici olmasını sağlayabilecek özelliktedir.

\subsubsection{Duygusallık}

Çocukların metinlerle bağ kurduğu, romandaki kahramanlarla aynı duyguları yaşadığ yadsınamaz bir gerçektir. Bu nedenle "duygunun aşırı ölçüde zorlandığ 1 , kullanılmaya çalışıldığ 1 yaşam durumları, çocukların insan doğasını yaşam gerçeğini fark etmelerine engel olur" (Sever, 2017, s. 138-139). Aşırı derecede üzüntü veren, acıkl1, çocuğu karamsarlığa iten konular veya bu gibi ögeler kurgularda kullanılmamalıdır. Ancak, aşırı olmadığı sürece duygusallıktan yoksun bir roman da yüzeysel kalabilir. Bu nedenle, kurguda duygusallık içeren unsurlar dengeli bir biçimde verilmelidir. Romanda, Çırak Hlapić'in Çatık Usta'dan gördügü zulüm biraz acıklıdır ancak bu kısımlarda detay verilmemekle birlikte dayak veya zulümle ilgili yerler çok kısa tutulmuştur. Acıklı denilebilecek bir paragrafin hemen arkasına eğlenceli bir paragraf gelmektedir. Romanın, çocukların duygularını olumlu yönde etkileyeceği değerlendirilmektedir.

\subsubsection{Dil ve Anlatım}

Dil ve anlatım tüm metinler için çok önemlidir ancak çocuklar için oluşturulan bir metin için daha da önemlidir çünkü çocukların anlayabileceği kelimeler, cümle uzunluğu, benzetmeler, mecaz, deyim ve atasözleri sınırlıdır. Ayrıca, "çocuk kitaplarında anlatımın sadeliğine dikkat edilmeli; gereksiz ve bayağı sözcükler yer almamalıdır, duruluk, akıcılık, açıklık gibi unsurlar göz önünde bulundurulmalıdır" (Yalçın ve Aytaş, 2017, s. 93). Yazar, dışarıdan bir anlatıcı olarak bu romanı yazmıştır. Roman; sade, açık ve anlaşı1ır bir üslupla yazılmıştır. Kitapta en uzun cümle 25 kelimeden oluşmaktadır ancak anlatımın çocuğun anlam bağlantısını koparmayacağı değerlendirilmektedir ve kitapta devrik cümle yapısı yoktur. Gereksiz ve uzun tasvir yok denecek kadar azdır.

Romanda "kaderine boyun eğmek, paniğe kapılmak, ödü kopmak, çıtını çıkarmamak, havaya uçmak, hevesini almak, gökte ararken yerde bulmak" deyimler "uzun uzun, yavaş yavaş hızlı hızl, gide gide, salına salına, hüngür hüngür, zaman zaman, düşünceli düşünceli, eğri bügrrü " ikilemeler yer alırken atasözü veya argo bir ifade yer almamaktadır.

- Benzetmeler çocukların anlayabileceği benzetmelerdir: "Saçları aslan yelesi gibi dolgunmuş. Sesi ayıların sesi gibi gür ve sertmiş. Ev o kadar yüksekmiş ki en uçtaki pencereleri sanki aya değiyor gibiymiş. Sevinçten iki top gibi sıçrayıp yuvarlanmaya başlamışlar. Bu yıldız uzaktan göründüğünde gülümseyen bir nineyi andırlyormuş. Dolu taneleri köprünün üzerine çekiçlerle vuruluyormuş gibi küt küt sesler çıkarlyor. Yağmur, bardaktan boşanırcasına yağıyormuş. Otlar tavuk tüyleri gibi her tarafa saçılıyormuş..."

Romanın çevirisini ise anadili Türkçe olan, ikinci dil olarak Hırvatça öğrenen yani her iki dile ve bu dillerin kültürüne hâkim olan bir Makedonya Türk'ü tarafından Hırvatçadan Türkçeye çevrilmiştir. Çevirinin danışmanlığını Zagreb Üniversitesi Felsefe Fakültesi Türkoloji Bölüm 
kurucusu Prof. Dr. Ekrem Çaušević yapmıştır böylece romanın Türkçe çevirisi, gerekli akademik düzeltme ve değerlendirmelerden geçmiştir. Kitapta anlatım bozukluğu veya yazım ve noktalama yanlışı olan cümle yoktur.

\subsection{Kitabın Temel Eğitim İlkelerine Uygunluğuna İlişsin Bulgular}

Çocuk edebiyatı ürünlerinin eğitim boyutu tartışlagelen bir konudur. Çocuk elbette öncelikle evrensel değerlerle eğitilmelidir. "Çocuklara, bir heykeltıraşın mermere veya taşa şekil verdiği gibi şekil vermeye çalışılmamalıdır. Bundan uzaklaşmak için bazı eğitsel ve yazınsal ilkeler açısından çocuk edebiyatı ürününün çocuk edebiyatının temel ilkelerine uygunluğunun değerlendirilmesi gerekir. Bu değerlendirmelerin şu sorular etrafında yapılması yararlı olacaktır (Gönen, 2017, s. 36):

\section{- Kitapta, öğüt veren bir yaklaşım benimsenmiş midir?}

Romanda öğüt veren bir yaklaşım benimsenmemiştir ancak romanın giriş bölümünde "Fakat yine de hiçbir çocuk evinden kaçmasın. " cümlesi öğüt niteliği taşımaktadır. Çocuğa kazandırılmak istenen evrensel değerler, Çırak Hlapić'in yaşadıkları üzerinden hedef okuyucu yaş grubuna hissettirilmiştir. Bu bakımdan yazarın otoriter bir üslubunun olmadığı değerlendirilmektedir. midir?

- Kitap çocukları yaratıcı ve eleştirel düşünmeye ve araştırmaya teşvik etmekte

Roman, 1913 yılında çocuk edebiyatının çocukları eğitme işlevselliğinin geçerli olduğu fikir ortamında yazılmıştır. "19. yüzyılın ilk çocuk romanlarında, toplumda kadınlar gibi ötekileștirilmiş çocukların, toplumsal rollerini işlevsel hale getirmek amaçlanmıștır. Bu amaç doğrultusunda çocuk kahramanlar, büyük karakterlerin davranışlarını taklit etmiş; çocukların nasıl bir birey olacaklarına büyükler karar vermiştir. Dolayısıyla ilk çocuk romanlarında çocuk karakterlerin kendi kişilikleri olmadığı için büyükler onlara kendi isteklerine göre anlamlar yüklemiş ve hatta bu çocuk kahramanların kişilikleri bile ancak büyüdüklerinde işlev kazanmıştır" (Zima, 2011). Bu nedenle romanın, çocuğun yaratıcı ve eleştirel düşünmesi, çocuğu araştırmaya yönlendirmesi gibi çağdaş görüşleri taşımadığı değerlendirilmektedir. yapılmış mıdır?

- Kitapta, günümüz kadın ve erkek rollerine uygun şekilde cinsel roller ayrımı

Romanda, kadın ve erkek rolleri yazıldığı dönemin özelliklerine göre verilmiştir. Çırak Hlapić'in Gita'yı koruması, onu beslemek için çalışması ve bunu bir görev gibi üstlenmesi çocuk da olsa erkek rolünü ön plana çıkarmıştır. Çatık Usta'nın karısının; evde çalışıyor olması, Çırak Hlapić'e eziyet ederken kocasına sesini çıkaramaması, romanın tamamında kadınların edilgen konumda olması geleneksel bakış açısının göstergeleridir. Bu rol ayrımı, abartılı ya da romanın tamamını etkileyecek şekilde değildir.

\section{- Çocukların cinsel rolleri yanında kişilik gelişimlerine de olanak sağlanmış mıdır?}

Roman, çocukların kişisel gelişimlerine katkı sağlamaktadır. Çırak Hlapić'in cesareti, doğruluğu, yardımseverliği ve çalışkanlığı çocuklara örnek olması açısından önemlidir.

\section{- İnsan ilişkilerinde kaba güç ve şiddetin yerine iletişim kurmanın seçilmesi özendirilmiş midir?}

Romanda, bütün köy halkı Grga'nın annesine tepki gösterirken Hlapić'in anneyle konuşması ve ona yardım etmesi kaba güç ve şiddet yerine iletişimin önemini ortaya koymuştur. Hlapić, Graga ile karşılaşınca ona "Bana, Kara Adam'dan uzak duracağına söz ver. Oralarda dürüst ol. Bunları sana teslim etmem için veren gözü yaşlı annenin sözünü dinle." diyerek onu kötülüklerden korumak 
için iletişimi seçmiştir ve başarılı da olmuştur. Hlapić'in yaşlı sütçüye yardım etmesi için hizmetçiyi ikna etmesi de önemli bir örnektir.

\section{- Siyasi ideolojilerin dayatılmasından uzak durulmuş mudur?}

Romanda hiçbir ideolojik görüş yoktur.

\section{- Batıl inançlardan uzak durulmuş mudur?}

Romanda büyü, büyücü, fal gibi batıl inançlar yoktur.

\section{- Çocuklara belli değerler ve düşünceler benimsetilmeye çalışılmış mıdır?}

Çocuğa kazandırılması gereken doğruluk, dürüstlük, iyiliğin değeri, kötülüğün cezası gibi evrensel değerler dışında çocuğa benimsetilmeye çalışılan dini bir motif, bir dine veya inanışa özendirici bir olay, bir 1rk1 veya topluluğu aşağılama veya yüceltme gibi düşünceler bulunmamaktadır.

- Otoriteye boyun eğen, onu onaylayan bir yaklaşımdan uzak durulmuş mudur?

Çırak Hlapić'in Çatık Usta'nın zulmüne boyun eğmeyerek evinden ayrılması otoriteye boyun eğmediğinin bir göstergesidir. Ancak, romanda çocukların evden kaçmaması hususunun belirtilmesi de dikkate değerdir.

\section{Sonuç}

Hırvatistan'ın tarihi, sosyal ve kültürel birikimiyle oluşturduğu edebiyatı, yazarları hem tanınmakta hem de Hırvat yazarların kitapları tüm Avrupa dillerine çevrilmektedir. Hırvatistan'da kitap okuma oranı çok yüksektir. Kitap okuma bilinci, daha çocuk yaşlarda oturtulmaktadır. Birçok çocuk kitabı, romanı ilkokullarda zorunlu olarak okutulmaktadır. Zorunlu okutulan kitaplardan biri de incelemesi yapılan "Çırak Hlapić'in Olağanüstü Maceraları"'dır. Roman, Rijeka Hırvat-Türk Derneği ve Zagreb Üniversitesi Felsefe Fakültesi Türkoloji Bölümünün katkılarıyla 2014 y1lında Türkçeye kazandırılmıştır, Nesin Yayınevi Çocuk Cenneti Kitaplığı tarafından basılmış, romanın satışı devam etmektedir.

Roman hakkında çeşitli çalışmalar yapılmıştır. Majhut (2008) çalışmasında romanı, kültürel değer aktarımı açısından incelemiş; Rezo (2013), Hlapić'in ayrıldığı evi, yolculuk boyunca gittiği mekânları, (ahır, köprü, taş ocağı, sirk), köy ve şehir hayatını mekânsal algı kavramıyla incelemiştir. Dujić (2018), romandaki kadın ve erkek karakterleri, göçebe erkeklerin ve yuva yapan kadının biyolojik ve sosyal rolleriyle bağlantılı olarak değerlendirmiştir. Huljev (2018), çalışmasında romanın komşulara duyulan sevgi, hayvanlara empati ve fakir veya öteki insanlara hoşgörü, anlayış, arkadaşlık, aile, nezaket, cesaret ve bilgelik gibi değerleri işlediğini ancak çocuğu eleştirel düşünmeye yönlendirmediğini ifade etmiştir.

Hırvat çocuk edebiyatı, Hırvat yazar Ivana Brlić-Mažuranić Türkiye'de pek bilinmemektedir. Bu çalışmada hem Hırvat çocuk edebiyatı hakkında bilgi vermeyi hem de Ivana Brlić-Mažuranić'in "Çırak Hlapić'in Olağanüstü Maceraları" adlı romanı yapısal ve eğitsel ilkeler bakımından incelemeyi amaçlanmıştır. Roman; içyapı (tema, konu, ileti, karakterler, plan, dil ve anlatım özellikleri), dış yapı özelliklerine (boyut, kapak-cilt, kâğıt, sayfa düzeni, harflerin büyüklüğü, resim) ve temel eğitim ilkelerine uygunluğuna ilişkin bulgulara göre incelenmiştir.

- Romanın dış yapı özelliklerinden olan kitabın boyutu, çocuğun taşıyabileceği özelliktedir.

- Kapaktaki resim, romanın içeriğiyle uyumludur, kapaktaki başlık ise çocukta merak duygusuna hitap etmektedir. Kapak ve cilt çocuklar için dayanıklıdır. uygundur.

- Romanın kâğıdı, yıpranmaya karşı dayanıklı mat bir malzemedendir. Bu da çocuklar için 
- Kitabın sayfa düzeni çocukların rahatça okuyabileceği şekilde tasarlanmıştır. Resimler sayfa düzeni içerisinde belli bir uyuma göre dağıtılmaması resim-metin uyumu açısından romanın eksik kaldığı değerlendirilmektedir.

- Roman hitap ettiği 9-12 yaş hedef okuyucu metinlerde uygun yazı puntosu kullanılmıştır.

- Romanda kullanılan resimler, metin ile ilişkili ve uyumludur ancak resimlerin profesyonel çizim olmadığ 1 değerlendirilmektedir.

- Romanın iç yapısal özelliklerinden temanın romanda okuyucuya hissettirildiği ve olayların temayı destekleyecek şekilde kurgulandığı değerlendirilmektedir.

- Konu, çocukları ilgisini çekecek ve çocukta merak duygusunu canlı tutacak şekildedir. Çatışmalar, çocuğun psikolojisini zorlayacak şekilde tasarlanmamıştır. Romanda dikkat çeken bir diğer husus da aşırı detay, tasvir, temanın veya konunun dışında gereksiz unsurların olmamasıdır.

- İyiliğin, çalışkanlığın, zekânın, cesaretin insanlar için çok önemli erdemler olduğu romanın ana ve alt iletileridir. Romanda, Kara Adam'ın bir şekilde cezasını bulması ile kötülerin sonunun iyi olmayacağ 1 fikri çocuğa sezdirilmektedir.

- Romandaki karakterler, abartılı, olağanüstü değildir. Yazarın, Çırak Hlapić dahil karakterlerini fiziksel özellikleriyle değil psikolojik ve davranışsal özellikleriyle ön plana çıkarmasının çocuk okuyucuyu olumlu etkileyeceği değerlendirilmektedir. Çırak Hlapić, her çocuğun özdeşim kurabileceği, içindeki iyiliği davranışa dökebilecek bir karakterdir. Yazarın iyiliğin temsilcisi olarak kurguladığı Hlapić ile kötülüğün temsilcisi Kara Adam arasındaki farkı başarılı bir şekilde ortaya koyması da okuyucuya doğru davranışa yönlendirebilecek şekildedir.

- Romanın, Çırak Hlapić’in yedi gün süren yolculuğunda karşılaştığı olayları, iyi veya kötü insanları, mantıklı rastlantılarla, okuyucuda merak duygusunu canlı tutarak ve aşırı duygusallıktan uzak bir planla kurgulandığı değerlendirilmektedir.

- Romanda dil ve anlatım açısından çocuğa görelik ilkesine uygundur. Anlatımda açıklık ve akıcılık görülmektedir. Romanda çocukların günlük hayatlarında kullandığı kelimelere yer verilmiştir. Argo, küfür gibi dil yapıları yer almamaktadır.

- Roman, temel eğitim ilkelerine göre değerlendirildiğinde ise romanda öğüt veren baskıcı bir anlatımın olmadığı mesajların daha çok hissettirme yoluyla çocuğa kazandırılmaya çalışılmıştır. Romanın yazıldığı yüzyılın özelliklerini taşıması nedeniyle çocuğa eleştirel düşünme gibi çağdaş değerleri kazandırmaya yönelik olmadığı değerlendirilmektedir.

- Romanın kadın-erkek ilişkilerinde, romanın tamamında kadınların edilgen konumda olması geleneksel bakış açısının göstergeleridir. Bu rol ayrımı, abartılı ya da romanın tamamını etkileyecek şekilde olmamakla birlikte yazıldığı yüzyılın özelliklerini yansıtmaktadır. Roman, çocukların kişisel ve cinsel kimliklerini olumsuz etkileyecek unsurlar taşımamaktadır.

- Romanın kahramanının kaba kuvvet yerine iletişimi öncelemesi romanın eğitsel açıdan olumlu bir niteliğidir. Romansa siyasi, dini veya başka düşüncelere yönlendirecek unsurlar bulunmamaktadır. Romanda kahramanının haksızlığa uğradığı zaman otoriteye boyun eğmeyerek evden kaçması ancak yazarın da çocukların evden kaçmaması gerektiğini romanın girişinde belirtmesi dikkate değerdir.

Sonuç olarak roman, çocuk eğitimi açısından da önemlidir çünkü romanın tamamında iyilik ön plandadır. Yaşlılara, çocuklara, korunmaya muhtaç herkese yardım etmenin erdemi, ekmeğiniyemeğini paylaşmanın yüceliği vurgulanmaktadır. Çırak Hlapić'in, Grga'ya şans vermesi, ona iyiliği nasihat etmesi, Grga'nın içindeki iyi insanı ortaya çıkarması da çocuk okuyucu için çok önemli bir mesajdır. Bencil, kendisinden başkasını düşünmeyen çocukların sayısının hızla arttığı bu yüzyılda 
böyle romanların çocuklara faydalı olacağı değerlendirilmektedir. Eğitsel ilkelere ve çocuklar için yazılmış yapıtları değerlendirme başlıklarına göre incelenen bu roman, hem çocukta okuma ilgisi uyandıracak ve hem de çocuğa okuma alışkanlığı kazandırabilecek niteliklere sahip olduğu için ilkokul dördüncü sınıftan başlayarak tüm çocuklara tavsiye edilmektedir.

\section{Kaynakça}

Batinić, Š. (2004). Zabava i pouka dobroj djeci i mladeži: hrvatski časopisi za djecu i mladež od 1864. do 1945, Hrvatski školski muzej, Zagreb.

Boşnakça-Türkçe, Türkçe-Boşnakça Standart Sözlük (2012). Fono Özel Eğitim Kurumları ve Yayın Dağıtma San. ve Tic. Ltd. Şti., s. 6-8. İstanbul.

Crnković, M. (1970). Ivana Brlić Mažuranić i hrvatska dječja književnost: Zbornik radova. Zagreb: Izdavačko knjižarsko poduzeće Mladost.

Crnković, M. (1978). U službi pedagogije ili umjetnost, u: Hrvatska dječja književnost, Školska knjiga, str. 36-41 Zagreb.

Çer, E. (2016). Türkçe öğretiminde çocuğa görelik ilkesine uygun edebiyat yapıtlarının önemi. Elementary Education Online, 2016; 15(4): 1399-1410, İlköğretim Online, 15(4), 13991410, 2016. http://ilkogretim-online.org.tr doi: http://dx.doi.org/10.17051/io.2016.22814

Diklić, Z. (1997). Izabrana djela /Ivana Brlić-Mažuranić; priredio Zagreb: Matica hrvatska.

Dilidüzgün, S. (2004). Çağdaş çocuk yazını-yazın eğitimine atılan ilk adım. İzmir: Tudem Yayınları.

Dujić, L. (2018). Labour and gender in the strange adventures of hlapić the apprentice and tales of long ago. Libri et liberi : časopis za istraživanje dječje književnosti i kulture, Vol. 7 No. 1 , Zagreb. https://doi.org/10.21066/carcl.libri.2018-07(01).0003

Fališevac, D. (2013). Dijete i djetinjstvo u staroj hrvatskoj književnosti, u: Slike starog Dubrovnika, Matica hrvatska, str. 205-226. Zagreb.

Gönen, M. (2017). Çocuk Edebiyatı Yazarı ve Çizeri Olarak Feridun Oral'in Çocuk Edebiyatımızdaki Yeri ve Eğitsel Değerler. Afyon Kocatepe Üniversitesi Sosyal Bilimler Enstitüsü Türkçe Eğitimi Anabilim Dalı Yüksek Lisans Tezi, Afyon.

Hameršak, M. ve Zima, D. (2015). Uvod u dječju književnost, Leykam international, Zagreb.

Huljev, A. (2018). Odgojne vrijednosti u romanima Ivane Brlić- Mažuranić: udžbenička analiza, (Educational Values in the Novels by Ivana Brlić- Mažuranić: A Textbook Analysis) tom III / Abidović, Albina - Brčko: Evropski univerzitet Brčko distrikt, 2018. str. 339-351.

Majhut, B. (2008). Reception of the novel Čudnovate zgode šegrta Hlapića (The marvellous adventures of Hlapić the apprentice) by Ivana Brlić-Mažuranić. Nova Croatica: časopis za hrvatsku književnost $i$ kulturu, Vol. 2 [32] No. 2 [52] Zagreb. URI https://hrcak.srce.hr/174662

Mihanović-Salopek, H. (1997). Ivana Brlić-Mažuranić, Priče iz davnine; Čudnovate zgode šegrta Hlapića, (ur.) Vinkovci: Riječ.

Neydim, N. (2013, 05.13). Edebiyat ders verme aract değildir. (Ü. Avc1, Röportaj Yapan) https://www.haberturk.com/yazarlar/umran-avci/843930-edebiyat-ders-verme-aracidegildir adresinden 19 Mart 2019 tarihinde alınmıştır.

Oğuzkan, F. (2006). Yerli ve yabancı örneklerle çocuk edebiyatı. Ankara: Anı Yayıncılık. 
Özdemir, E. (1995). Eleştirel okuma. Ankara: Bilgi Yayınevi.

Plašagić, B. (2003). Hrvatski dječji časopisi od 1864. do 1950. godine, Udruga umjetnika "August Šenoa", Zagreb.

Rezo, V. (2013). Notions of space in The Brave Adventures of Hlapich the Apprentice. Libri et liberi: časopis za istraživanje dječje književnosti $i$ kulture, Vol. 2 No. 2. Zagreb. URI https://hrcak.srce.hr/119479

Sever, S. (2006). Çocuk edebiyatı öğretimi nasıl olmalıdır? II. Ulusal Çocuk ve Gençlik Edebiyatı Sempozyuтu Ankara Üniversitesi Eğitim Bilimleri Fakültesi (04-06 Ekim 2006). Ankara

Sever, S. (2017). Çocuk ve edebiyat (9.baskı). İzmir: Tudem Yayınları.

Težak, D. ve Crnković, M. (2002). Povijest hrvatske dječje književnosti: od početaka do 1955. godine, Znanje, Zagreb.

Težak, D. (2010). Književnost za djecu (Dječja književnost) u: Hrvatska književna enciklopedija, sv. 2, Gl-Ma/ ur. Velimir Visković, Leksikografski zavod Miroslav Krleža, str. 331-334. Zagreb.

Türkçe Sözlük (2005). Ankara: Türk Dil Kurumu Yayınları

Yalçın, A. ve Aytaş, G. (2017). Çocuk edebiyatı (9. Baskı). Ankara: Akçă̆ Yayınları.

Yıldırım, A. ve Şimşek, H. (2000). Sosyal bilimlerde nitel araştırma yöntemleri (2. Baskı). Ankara: Seçkin Yayıncılık.

Zima, D. (2001). Ivana Brlić-Mažuranić, Zavod za znanost o književnosti Filozofskog fakulteta Sveučilišta u Zagrebu, Zagreb.

Zima, D. (2011). Kraći ljudi: povijest dječjeg lika u hrvatskom dječjem romanu, Školska knjiga, Zagreb.

Zima, D. (2013). Stogodišnjica romana. Hrvatska revija, 3: 20-26. Zagreb. Pregled bibliografske jedinice broj: 1003855 . 